\title{
Preparation of HeLa Total Membranes and Assay of Lipid-inhibition of Serine Palmitoyltransferase Activity
}

Muthukumar Kannan, Deanna L. Davis, John Suemitsu, Christopher D. Oltorik and Binks Wattenberg*

Dept. of Biochemistry and Molecular Biology, Virginia Commonwealth University School of Medicine, Richmond, VA 23298, USA

*For correspondence: brian.wattenberg@vcuhealth.org

\begin{abstract}
[Abstract] Serine palmitoyltranferase (SPT) is a pyridoxal 5' phosphate (PLP)-dependent enzyme that catalyzes the first and rate-limiting step of de novo synthesis of sphingolipids. SPT activity is homeostatically regulated in response to increased levels of sphingolipids. This homeostatic regulation of SPT is mediated through small ER membrane proteins termed the ORMDLs. Here we describe a procedure to assay ORMDL dependent lipid inhibition of SPT activity. The assay of SPT activity using radiolabeled L-serine was developed from the procedure established by the Hornemann laboratory. The activity of SPT can also be measured using deuterated L-serine but it requires mass spectrometry, which consumes money, time and instrumentation. The ORMDL dependent lipid inhibition of SPT activity can be studied in both cells and in a cell free system. This assay procedure is applicable to any type of mammalian cell. Here we provide the detailed protocol to measure SPT activity in the presence of either short chain (C8-ceramide) or long chain ceramide (C24-ceramide). One of the greatest advantages of this protocol is the ability to test insoluble long chain ceramides. We accomplished this by generating long chain ceramide through endogenous ceramide synthase by providing exogenous sphingosine and 24:1 acyl CoA in HeLa cell membranes. This SPT assay procedure is simple and easy to perform and does not require sophisticated instruments.
\end{abstract}

Keywords: Serine palmitoyltranferase, Ceramide synthases, Sphingolipids, ORMDL, Ceramide, Endoplasmic reticulum, Homeostasis

[Background] Serine palmitoyltranferase (SPT) is a multi-subunit enzyme that is widely expressed in eukaryotes and some prokaryotes (Hanada et al., 1997; Ikushiro et al., 2001; Hornemann et al., 2007). The first and rate-determining step of the sphingolipid biosynthetic pathway is catalyzed by SPT, producing 3-keto dihydrosphingosine from the condensation of serine and palmitoyl-CoA (Williams et al., 1984; Hanada, 2003). The mammalian SPT complex is composed of two large subunits and one small subunit. The large subunits are termed SPTLC1 and SPTLC2 and the small subunits are termed ssSPT (Nagiec et al., 1994; Lowther et al., 2012). SPT requires all three subunits to form a functional protein complex (Han et al., 2009). In some circumstances mammalian SPT is also composed of another large subunit termed SPTLC3 (Hornemann et al., 2009), which substitutes for SPTLC2. The functional SPT complex is formed by pairing SPTLC1 with either SPTCL2 or SPTLC3 and SSSPT. The active site of SPT resides in the SPTLC2 or SPTLC3 subunit. The substrate preference between the complex incorporating SPTLC2 and SPTLC3 differs. SPTLC2 prefers palmitoyl CoA. SPTLC3 prefers myristoyl- 
CoA (Hornemann et al., 2009). In certain situations SPT also incorporates alanine or glycine rather than serine into the precursor sphingolipid to generate a deoxysphingolipid base (Gable et al., 2010; Ferreira et al., 2018). SPT forms a stable complex with another ER resident protein termed ORMDL. This SPTORMDL interaction is crucial to maintain the homeostatic regulation of de novo biosynthesis of sphingolipids (Siow and Wattenberg, 2012; Davis et al., 2018). There are three closely related ORMDL family members found in mammals (Breslow et al., 2010; Siow and Wattenberg, 2012). We previously showed that increased levels of cellular ceramide inhibit SPT activity in an ORMDL-dependent manner in HeLa cells (Davis et al., 2019). The detailed mechanism behind the homeostatic regulation of SPT activity by the ORMDLs is largely unknown. SPT forms a stable complex with ORMDL, irrespective of cellular levels of ceramide. We propose that ceramides bind to either the ORMDLs or to the SPT-ORMDL complex to trigger the inhibition of SPT activity. We recently developed a cell free system in which membranes were isolated from HeLa cells and used to test the response of SPT activity to elevated sphingolipid. This system measures SPT activity in the presence or absence of ceramides with artificially short and natural chain lengths (Davis et al., 2019). We established the assay of ORMDL dependent lipid inhibition of SPT activity as a platform to test the functional interaction of SPT and ORMDL. This SPT assay procedure was developed from the procedure of Rutti et al. (2009). The cell free in vitro system has many advantageous over in vivo systems and both systems yield similar results (Davis et al., 2018). Using this cell free reconstitution system, we have determined that ORMDL dependent regulation of SPT activity is not mediated by post transcriptional or post translational mechanisms (Davis et al., 2018). This cell free system is a powerful tool to explore the detailed mechanism behind the homeostatic regulation of SPT by ORMDLs.

\section{Materials and Reagents}

1. Vacuum filtration unit $(0.2 \mu \mathrm{m})(\mathrm{VWR}$, catalog number: 10040-436)

2. T150 flask (Cyto One, catalog number: CC7682-4815)

3. 24-well plate (Cyto One, catalog number: CC7682-7524)

4. 26 gauge needle (BD, catalog number: 305110-269)

5. $1 \mathrm{ml}$ syringe (BD, catalog number: 309659$)$

6. Thickwall Polycarbonate Tubes for Ultracentrifuge Rotors (Beckman Coulter, catalog number: 343776)

7. Screw cap tubes-2 $\mathrm{ml}$ (Axygen, catalog number: SCT-200-C-S)

8. Scintillation tubes (PerkinEImer, catalog number: 6000292)

9. Disposable cell lifters-sterile (Fisher Scientific, catalog number: 08-100-240)

10. HeLa cells (ATCC, catalog number: CCL-2 )

11. Dulbecco's minimal essential medium (DMEM Media) (Gibco, catalog number: 11960-044)

12. Fetal Bovine Serum (Gemini, catalog number: 900-108)

13. HEPES (Fisher Scientific, catalog number: BP310-1)

14. Penicillin-streptomycin, 10,000 U/ml (Gibco, catalog number: 15140-122) 
15. Glutamine (Gibco, catalog number: $25030-081$ )

16. Trypsin-EDTA (Gibco, catalog number: 25200-056)

17. Collagen (Sigma, catalog number: C9791)

18. Sucrose (Fisher Scientific, catalog number: S5-3)

19. Myriocin (Cayman, catalog number: 63150)

20. Fumonisin B1 (Cayman, catalog number: 62580)

21. Tris (Fisher Scientific, catalog number: BP 152-5)

22. Complete mini EDTA-free Protease Inhibitor Cocktail (Roche, catalog number: 04693159001)

23. OptiMEM (Gibco, catalog number: 31985-070)

24. FA-Free BSA (Fisher, catalog number: BP9704-100)

25. Chloroform (Fisher, catalog number: C297-4)

26. Methanol (Fisher, catalog number: A452-4)

27. Liquid nitrogen

28. C8 ceramide (Avanti, catalog number:860508)

29. Sphingosine (Avanti, catalog number: 860490)

30. Palmitoyl CoA (Sigma, catalog number: P9716-10MG)

31. 24:1 Coenzyme A (Avanti, catalog number: 870725 )

32. Potassium hydroxide (Fisher, catalog number: P250-500)

33. DTT (Sigma, catalog number: D0632)

34. EDTA (Fisher, catalog number: S311-500)

35. Pyridoxal 5' phosphate (Sigma, catalog number: P9255)

36. L-Serine (Sigma, catalog number:S4500)

37. L-[ $\left.{ }^{3} \mathrm{H}(\mathrm{G})\right]$-Serine (PerkinElmer, catalog number: 2477301)

38. Ecolite-Scintillation fluid (MP Biomedicals, catalog number: 882475)

39. Beta max-Scintillation fluid (MP Biomedicals, catalog number: 880020)

40. Serine free MEM (Gibco, catalog number: 11095-080)

41. Magnesium chloride (Fisher Scientific, catalog number: M87-100)

42. DMEM complete medium (see Recipes)

43. C8-ceramide (see Recipes)

44. Sphingosine (see Recipes)

45. Palmitoyl CoA (see Recipes)

46. 24:1 CoenzymeA (see Recipes)

47. Fatty acid free BSA (see Recipes)

48. $1 \mathrm{mM}$ C8-ceramide (see Recipes)

49. Methanol (see Recipes)

50. Myriocin (see Recipes)

51. Fumonisin B1 (see Recipes)

52. Chloroform:methanol (2:1) (see Recipes)

53. 10x Phosphate buffered saline (PBS) pH 7.4 (see Recipes) 
54. Alkaline methanol (see Recipes)

55. Alkaline water (see Recipes)

56. Digitonin (see Recipes)

57. Pyridoxal 5' phosphate (see Recipes)

58. L-serine stock (see Recipes)

59. $0.05 \%$ Trypsin (see Recipes)

60. Scintillation fluid (see Recipes)

61. Collagen (see Recipes)

62. Collagen coating (see Recipes)

\section{Equipment}

1. Cell culture Hood (LABCONCO, catalog number: 36213043726 )

2. $-80^{\circ} \mathrm{C}$ freezer (Thermo Scientific, model: 5815 )

3. $\mathrm{CO}_{2}$ incubator (Thermo Scientific, model: 3110 )

4. KONTES Dounce glass homogenizer (VWR, catalog number: KT885300-0007)

5. Table top refrigerated centrifuge with swingout rotor (Eppendorf, model: 5810)

6. Table top Ultracentrifuge (Beckman Coulter, model: Optima MAX-XP)

7. TLA 120.2 rotor (Backman Coulter, S/N: 16U1971)

8. Scintillation counter (Backman Coulter, model: LS6500)

9. Water bath (Thermo Scientific, model: 2354)

10. Nitrogen gas (Airgas, catalog number: NI UHP300)

11. $\mathrm{CO}_{2}$ gas (Airgas, catalog number: CD USP50 )

12. Vortexer (Vortex-Genie 2, model: SI-0236)

13. Table top high speed centrifuge (Thermo Scientific, model: accuSpin Micro 17)

\section{Procedure}

A. Extraction of L-[ $\left[{ }^{3} \mathrm{H}(\mathrm{G})\right]$-serine

1. Handle and store $L-\left[{ }^{3} H(G)\right]$-Serine only in designated and authorized locations with proper precautions.

2. Dispose radioactive waste in specially designated waste containers.

3. Take $2 \mu \mathrm{l}$ of serine before and after extraction and measure radioactivity to calculate the recovery of $L-\left[{ }^{3} \mathrm{H}(\mathrm{G})\right]$-Serine.

4. Dispense $0.2 \mathrm{ml}$ of the $\left[{ }^{3} \mathrm{H}\right]$-serine into a $2 \mathrm{ml}$ screw cap tube, then add $0.5 \mathrm{ml}$ of chloroform:methanol (2:1 ratio) to the tube.

5. Vortex the tube for $1 \mathrm{~min}$.

6. Centrifuge the tube at $16,200 \times g$ for $2 \mathrm{~min}$ at room temperature in a high speed centrifuge.

7. Transfer the upper aqueous phase into fresh $2 \mathrm{ml}$ screw cap tubes. 
8. Place the tubes into the house vacuum flask for $30 \mathrm{~min}$ to remove the traces of organic solvents.

9. Measure the radioactivity after extraction to calculate specific activity of $L-\left[{ }^{3} \mathrm{H}(\mathrm{G})\right]$-serine.

10. Use this extracted $\left[{ }^{3} \mathrm{H}\right]$-serine to measure SPT activity in cells and membranes.

11. Extracted $\left[{ }^{3} \mathrm{H}\right]$-serine will give less background, i.e., low counts with myriocin treatment in SPT assay.

B. Assay of lipid inhibition of serine palmitoyltransferase (SPT) activity in intact HeLa cells

1. Grow HeLa cells in DMEM complete medium and maintain cells in a $\mathrm{CO}_{2}$ incubator at $37{ }^{\circ} \mathrm{C}$ and $5 \% \mathrm{CO}_{2}$.

2. On day-1, plate HeLa cells $\left(7 \times 10^{4}\right.$ cells/well) in a collagen coated 24 -well plate with $1 \mathrm{ml}$ of DMEM complete medium.

3. See Recipes for the procedure of collagen coating in 24-well plates.

4. Divide cells into 4 groups for control, C8-ceramide, myriocin treatment and protein analysis.

5. Prepare 4 wells for each group and use average value for calculations.

6. Myriocin is a specific inhibitor for SPT and is a negative control for this assay.

7. On day-2, add $10 \mu \mathrm{M}$ C8-ceramide or $1 \mu \mathrm{M}$ myriocin to the cells and incubate for $1 \mathrm{~h}$ in a $\mathrm{CO}_{2}$ incubator, see recipe for $\mathrm{C} 8$-ceramide and myriocin preparation.

8. Incubate control cells with methanol-BSA complex.

9. After $1 \mathrm{~h}$ remove C8-ceramide or myriocin and gently wash cells with $0.25 \mathrm{ml}$ of PBS at room temperature.

10. Measure SPT activity by adding $0.25 \mathrm{ml}$ of extracted ${ }^{3} \mathrm{H}$-serine to the cells in serine free MEM media ( $5 \mu \mathrm{Ci} / \mathrm{ml}$ of serine free media) and incubate cells in a $\mathrm{CO}_{2}$ incubator for $1 \mathrm{~h}$ at $37^{\circ} \mathrm{C}$.

11. After $1 \mathrm{~h}$, remove radioactive serine and gently wash cells with $0.25 \mathrm{ml}$ of PBS at room temperature.

12. Stop the reaction by adding $400 \mu \mathrm{l}$ of alkaline methanol and scrape the cells using plastic cell lifters.

13. Transfer cells into $2 \mathrm{ml}$ screw cap tubes.

14. Extract total sphingolipids under alkaline conditions as described below in Section $\mathrm{H}$.

15. Refer to Figure 1A in Davis et al. (2019) and Figure 2A in Siow et al. (2015) for results.

C. Assay of SPT activity in Permeabilized HeLa cells

1. Plate HeLa cells $\left(7 \times 10^{4}\right.$ cells/well $)$ in a collagen coated 24 -well plate and incubate in a $\mathrm{CO}_{2}$ incubator for $24 \mathrm{~h}$.

2. Divide cells into 4 groups for control, C8-ceramide, myriocin treatment and protein analysis.

3. Prepare 4 wells for each group and use average value for calculations.

4. After $24 \mathrm{~h}$, permeablize HeLa cells with $0.02 \%$ digitonin prepared in Opti-MEM.

5. Add $250 \mu \mathrm{l}$ of $0.02 \%$ digitonin and incubate cells for $3 \mathrm{~min}$ at $37^{\circ} \mathrm{C}$.

6. After $3 \mathrm{~min}$, remove digitonin and gently wash cells with $0.25 \mathrm{ml}$ of PBS at room temperature. 
7. Prepare preincubation medium, $50 \mathrm{mM}$ HEPES pH8.0, $1 \mathrm{mM}$ EDTA and $20 \mu \mathrm{M}$ pyridoxyl 5'phosphate.

8. Dilute C8-ceramide or myriocin with preincubation media and pre-warmed to $37^{\circ} \mathrm{C}$.

9. Add $200 \mu \mathrm{l}$ of preincubation medium with or without $10 \mu \mathrm{M}$ C8-ceramide or $1 \mu \mathrm{M}$ myriocin to permeabilized cells.

10. Incubate cells at $37^{\circ} \mathrm{C}$ for $30 \mathrm{~min}$ in a $\mathrm{CO}_{2}$ incubator.

11. After $30 \mathrm{~min}$ add $200 \mu \mathrm{l}$ of labelling media to each well, contains $2 \mu \mathrm{Ci}$ of extracted $\left[{ }^{3} \mathrm{H}\right]$-serine, $1 \mathrm{mM}$ L-serine, and $50 \mu \mathrm{M}$ palmitoyl-CoA prepared in preincubation medium.

12. Incubate cells for $60 \mathrm{~min}$ in a $\mathrm{CO}_{2}$ incubator.

13. After $60 \mathrm{~min}$ remove the labelling media.

14. Stop the reaction by adding $400 \mu$ of alkaline methanol and scrape the cells using plastic cell lifters.

15. Transfer cells into $2 \mathrm{ml}$ screw cap tubes for lipid extraction.

16. Extract total sphingolipids under alkaline condition as described below in Section $\mathrm{H}$.

17. Refer to Figure $1 A$ in Davis et al. (2019) and Figure 2A-B in Siow and Wattenberg (2012) for results.

D. Preparation of HeLa cell lysate

1. Seed $3 \times 10^{6}$ HeLa cells into one T-150 flask with DMEM complete medium.

2. Grow HeLa cells for $48 \mathrm{~h}$ in a $\mathrm{CO}_{2}$ incubator to achieve $90-95 \%$ confluency.

3. Remove the DMEM complete media and wash cells with $4 \mathrm{ml}$ of PBS at room temperature.

4. Add $4 \mathrm{ml}$ of $0.05 \%$ trypsin to cells and incubate for $2 \mathrm{~min}$ at room temperature.

5. After $2 \mathrm{~min}$, remove trypsin and incubate cells at $37^{\circ} \mathrm{C}$ for $5 \mathrm{~min}$.

6. Harvest cells with $10 \mathrm{ml}$ of ice cold DMEM complete media.

7. Collect cells by centrifugation for $10 \mathrm{~min}$ at $72 \times \mathrm{g}$.

8. Wash cells with $10 \mathrm{ml}$ of ice cold PBS.

9. Resuspend cells in $1.6 \mathrm{ml}$ of swelling buffer (10 mM Tris $\mathrm{pH} 7.5,15 \mathrm{mM} \mathrm{KCl}$ and $1 \mathrm{mM} \mathrm{MgCl}$ ) and incubate on ice for $15 \mathrm{~min}$.

10. To this, add $534 \mu \mathrm{l}$ of $1 \mathrm{M}$ sucrose, $7 \mu \mathrm{l}$ of $200 \mathrm{mM}$ EDTA and $80 \mu \mathrm{l}$ of protease inhibitors cocktail from $25 x$ stock.

Note: $25 x$ stock made by dissolving 1 protease inhibitor tablet in $2 \mathrm{ml}$ of water.

11. Homogenize the cells on ice with a $7 \mathrm{ml}$ Dounce homogenizer using pestle-B with 30 to 40 strokes.

12. Centrifuge the homogenate to remove unbroken cells and nuclei at $72 \times g$ for 10 min at $4{ }^{\circ} \mathrm{C}$ with a swinging bucket rotor and collect the supernatant.

13. Pass the cell free lysate through a 26 gauge needle with $1 \mathrm{ml}$ syringe for 10 times.

14. Aliquot $100 \mu \mathrm{l}$ lysate into $1.5 \mathrm{ml}$ tubes, snap freeze with liquid nitrogen and store at $-80^{\circ} \mathrm{C}$ until further analysis. 
E. Preparation of total membrane

1. Prepare cell free lysate as described above in Section $D$.

2. Transfer $1 \mathrm{ml}$ of cell free lysate to each clean thick wall ultra-centrifuge tubes then centrifuge at $434,513 \times \mathrm{g}$ for $20 \mathrm{~min}$ at $4{ }^{\circ} \mathrm{C}$ in a TLA 120.2 rotor.

3. Discard the supernatant.

4. Resuspend the membrane pellet with $500 \mu \mathrm{l}$ of membrane resuspension buffer $(250 \mathrm{mM}$ Sucrose, $25 \mathrm{mM}$ Tris, $\mathrm{pH} 7.4$ and $20 \mu \mathrm{l}$ of protease inhibitors cocktail from 25x stock) and homogenize with the Dounce homogenizer using pestle-B with 10 strokes.

5. Pass the membrane through a 26 gauge needle with $1 \mathrm{ml}$ of syringe for 10 times.

6. Aliquot $100 \mu \mathrm{l}$ of membranes into $1.5 \mathrm{ml}$ tubes and snap freeze with liquid nitrogen and store at $-80^{\circ} \mathrm{C}$ until further analysis.

F. Assay of lipid inhibition of serine palmitoyltransferase activity in cell free lysate or total membranes

1. Perform in vitro SPT activity in $2 \mathrm{ml}$ screw cap tubes and total reaction volume of $200 \mu \mathrm{l}$.

2. For assay of SPT activity with short chain ceramide, incubate cell free lysate (100 $\mu \mathrm{g}$ total protein) or membrane (50 $\mu \mathrm{g}$ total protein) in a pre-incubation buffer with or without $10 \mu \mathrm{M}$ C8-ceramide or $1 \mu \mathrm{M}$ myriocin on ice for $40 \mathrm{~min}$.

3. Pre-incubation buffer contains, $50 \mathrm{mM}$ HEPES pH 8.0, $25 \mathrm{mM}$ DTT, $2 \mathrm{mM}$ EDTA and $20 \mu \mathrm{M}$ PLP.

4. After $40 \mathrm{~min}$, add $100 \mu \mathrm{l}$ of labelling mix then mix well.

5. Labelling mix contains, $2 \mathrm{mM}$ Serine, $100 \mu \mathrm{M}$ palmitoyl CoA, $2 \mu \mathrm{Ci}$ extracted $\left[{ }^{3} \mathrm{H}\right]$-serine.

6. Incubate tubes for $60 \mathrm{~min}$ at $37^{\circ} \mathrm{C}$.

7. Stop reaction by adding $400 \mu \mathrm{l}$ of alkaline methanol.

8. Extract total sphingolipid under alkaline conditions as described below in Section $\mathrm{H}$.

9. Refer to Figures $1 A, B, 2 A$ and $3 A$ in Davis et al. (2019) for results.

G. Assay of SPT activity with long chain ceramide

1. For generation of long chain ceramide in membranes, incubate $50 \mu \mathrm{g}$ of membrane with $20 \mu \mathrm{M}$ sphingosine and $50 \mu \mathrm{M}$ 24:1 CoA or $1 \mu \mathrm{M}$ myriocin or $50 \mu \mathrm{M}$ Fumonisin-B1 in a final volume of $100 \mu \mathrm{l}$ in a buffer containing $20 \mathrm{mM}$ HEPES pH 7.4, $25 \mathrm{mM} \mathrm{KCl}, 2 \mathrm{mM} \mathrm{MgCl}_{2}$ and $0.1 \%$ fatty acid free BSA.

2. Fumonisin-B1 is an inhibitor of ceramide synthases.

3. Incubate this reaction mix at $37^{\circ} \mathrm{C}$ for 60 min to generate ceramide with $24: 1$ acyl chain by endogenous ceramide synthases.

4. After $60 \mathrm{~min}$, add $100 \mu \mathrm{l}$ of labelling mix and incubate the tubes for additional $60 \mathrm{~min}$ at $37^{\circ} \mathrm{C}$.

5. Labelling mix contains 50 mM HEPES pH 8.0, 1 mM DTT, 10 mM EDTA, $20 \mu M$ PLP, 2 mM serine, $100 \mu \mathrm{M}$ palmitoyl $\mathrm{CoA}$ and $2 \mu \mathrm{Ci}$ extracted $\left[{ }^{3} \mathrm{H}\right]$ serine.

6. Stop the reaction by adding $400 \mu \mathrm{l}$ of alkaline methanol and extract lipids under alkaline conditions as described below in Section $\mathrm{H}$. 
7. Refer to Figure 2B-C in Davis et al. (2019) for results.

H. Extraction of total sphingolipids under alkaline condition

1. Add $100 \mu \mathrm{l}$ of chloroform to the tube contains cells or membrane or lysate with $400 \mu \mathrm{l}$ alkaline methanol.

2. Vortex the tubes and centrifuge for $1 \mathrm{~min}$ at $16,200 \times g$ in a high speed centrifuge.

3. Add $500 \mu \mathrm{l}$ of chloroform followed by $300 \mu$ l alkaline water and $100 \mu$ l of $2 \mathrm{~N} \mathrm{NH}_{4} \mathrm{OH}$ to separate aqueous and organic phases.

4. Vortex the tube for $1 \mathrm{~min}$ and spin at $16,200 \times \mathrm{g}$ for $1 \mathrm{~min}$ in a high speed centrifuge.

5. Aspirate the upper aqueous phase.

6. Add $1 \mathrm{ml}$ of alkaline water to the lower organic phase, vortex well then centrifuge for $1 \mathrm{~min}$ at $16,200 \times g$.

7. Aspirate the upper aqueous phase and repeat the above step 6 again.

8. Transfer $350 \mu \mathrm{l}$ of the lower organic phase into scintillation vials and dry under nitrogen gas.

9. Add $5 \mathrm{ml}$ of scintillation fluid, vortex well and count radioactivity using a scintillation counter.

\section{Data analysis}

A. Expression of in vitro and in vitro SPT activity as $\left[{ }^{3} \mathrm{H}\right]$-serine in total sphingolipids (CPM $\left./ \mathrm{mg} / \mathrm{min}\right)$.

1. Here we provide the results obtained from previously performed experiments and detailed steps to calculate in vivo and in vitro SPT activity with results obtained from previously performed experiments.

2. Table 1 shows results of in vitro SPT activity from HeLa cell membranes.

Table 1. Serine palmitoyltransferase activity in total membranes of HeLa cells

\begin{tabular}{|c|c|c|}
\hline Tube Number & Control (CPM) & Myriocin (CPM) \\
\hline Tube-1 & 659 & 55 \\
\hline Tube-2 & 649 & 43 \\
\hline Tube-3 & 571 & 45 \\
\hline Mean & 626 & 47 \\
\hline SD & 48 & 5 \\
\hline
\end{tabular}

3. Normalize the CPM values to $\mathrm{mg}$ of total protein ( $50 \mu \mathrm{g}$ of protein used for SPT assay)

Control: $626.5 / 0.05 \times 1=12,530 \mathrm{CPM} / \mathrm{mg}$

Myriocin: 47.6/0.05 × $1=952 \mathrm{CPM} / \mathrm{mg}$

4. Convert values to per $\mathrm{min}$ (SPT assay conducted for $60 \mathrm{~min}$ )

Control: $12530 / 60=208.8 \mathrm{CPM} / \mathrm{mg} / \mathrm{min}$

Myriocin: $952 / 60=15.8 \mathrm{CPM} / \mathrm{mg} / \mathrm{min}$

5. In vivo and in vitro SPT activity is expressed as $\left[{ }^{3} \mathrm{H}\right]$ serine in total sphingolipids (CPM/mg/min). 
B. Expression of in vitro SPT activity as $\left[{ }^{3} \mathrm{H}\right]$-serine in total sphingolipids $(\mathrm{pMol} / \mathrm{mg} / \mathrm{min})$

1. Total radioactivity in substrate (labelling mix) is $1,280,980$ CPM.

2. SPT reaction mix contains $200 \mathrm{nMol}$ of serine.

3. Consider $200 \mathrm{nMol}$ of serine is equivalent to $1,280,980 \mathrm{CPM}$.

4. Calculate specific activity from this value by using this formula, $\mathrm{nMol}$ of serine/CPM in substrate $\times$ mean CPM from SPT assay $=\mathrm{X}$ nMol, e.g., $200 / 1,280,980 \times 626=0.097 \mathrm{nMol}$ of $\left[{ }^{3} \mathrm{H}\right]$ serine in total sphingolipids.

5. Mean value of control SPT activity is $626 \mathrm{CPM}$.

6. Convert the above value to per mg protein, $0.097 / 0.05 \times 1=1.94 \mathrm{nMol} / \mathrm{mg}$ protein.

7. Convert the above value to per $\mathrm{min}, 1.94 / 60=0.032 \mathrm{nMol} / \mathrm{mg} / \mathrm{min}$.

8. Convert value from $\mathrm{nmol}$ to $\mathrm{pmol}$ by multiplying the above value by $1,000(0.032 \times 1,000=32$ $\mathrm{pMol} / \mathrm{mg} / \mathrm{min}$ ).

9. In vitro SPT activity is expressed as $\left[{ }^{3} \mathrm{H}\right]$-serine in total sphingolipids ( $\left.\mathrm{pMol} / \mathrm{mg} / \mathrm{min}\right)$.

\section{$\underline{\text { Recipes }}$}

1. DMEM complete medium

$500 \mathrm{ml}$ of DMEM media

$50 \mathrm{ml}$ of FBS

$10 \mathrm{ml}$ of HEPES $\mathrm{pH} 8.0$

$5 \mathrm{ml}$ of glutamine and $5 \mathrm{ml}$ Penicillin-streptomycin

2. C8-ceramide

$10 \mathrm{mg}$ of C8-ceramide dissolved in $1.174 \mathrm{ml}$ of methanol as a $20 \mathrm{mM}$ stock and store at $-20^{\circ} \mathrm{C}$

3. Sphingosine

$10 \mathrm{mg}$ of sphingosine dissolved in $3.34 \mathrm{ml}$ of methanol as a $10 \mathrm{mM}$ stock store at $-20^{\circ} \mathrm{C}$

4. Palmitoyl CoA

$10 \mathrm{mg}$ of palmitoyl CoA dissolved in $1.99 \mathrm{ml}$ of DMSO as a $5 \mathrm{mM}$ stock and store at $-20^{\circ} \mathrm{C}$

5. 24:1 CoenzymeA

Dissolve $5 \mathrm{mg}$ of $24: 1$ Coenzyme A in $857.2 \mu \mathrm{l}$ of DMSO to make $5 \mathrm{mM}$ Stock and store at $-20^{\circ} \mathrm{C}$

6. Fatty acid free BSA

Fatty acid free BSA prepared in PBS as a $2 \%$ stock and filter sterilize using $0.2 \mu \mathrm{m}$ syringe filter and store at $4{ }^{\circ} \mathrm{C}$

7. $1 \mathrm{mM} \mathrm{C8-ceramide}$

BSA complex $2.5 \mu \mathrm{l}$ of $20 \mathrm{mM}$ C8-ceramide mixed with $47.5 \mu \mathrm{l}$ of $2 \%$ fatty acid free BSA, made every time fresh

8. Methanol:BSA complex

$2.5 \mu \mathrm{l}$ of methanol mixed with $47.5 \mu \mathrm{l}$ of $2 \%$ fatty acid free BSA, made every time fresh 
9. Myriocin

Dissolve myriocin in methanol as a $1 \mathrm{mM}$ stock and store at $-20^{\circ} \mathrm{C}$

10. Fumonisin B1

$1 \mathrm{mg}$ of Fumonisin B1 dissolved in $92.4 \mu \mathrm{l}$ of DMSO as a $15 \mathrm{mM}$ stock and store at $-20^{\circ} \mathrm{C}$

11. Chloroform:methanol (2:1)

Mix 2 volume of chloroform and $1 \mathrm{ml}$ volume of methanol

12. $10 x$ Phosphate buffered saline (PBS) $\mathrm{pH} 7.4$

$15.4 \mathrm{mM} \mathrm{KH}_{2} \mathrm{PO}_{4}, 1.55 \mathrm{M} \mathrm{NaCl}$ and $28 \mathrm{mM} \mathrm{Na}_{2} \mathrm{HPO}_{4} \cdot 7 \mathrm{H}_{2} \mathrm{O}$ in water, if required adjust $\mathrm{pH}$ to 7.4 with $\mathrm{HCl}$

13. Alkaline methanol

Dissolve $0.7 \mathrm{~g}$ potassium hydroxide in $100 \mathrm{ml}$ of methanol

14. Alkaline water

Add $100 \mu \mathrm{l}$ of $2 \mathrm{~N} \mathrm{NH}_{4} \mathrm{OH}$ in $100 \mathrm{ml}$ water

15. Digitonin

Prepare $1 \%$ digitonin in DMSO as a stock and dilute to $0.02 \%$ in Opti-Mem

16. Pyridoxal 5' phosphate

Prepared in water as a $20 \mathrm{mM}$ stock and store at $-20^{\circ} \mathrm{C}$

17. L-serine stock

Prepare serine in water as a $50 \mathrm{mM}$ stock and store at $-20^{\circ} \mathrm{C}$

18. $0.05 \%$ Trypsin

Dilute stock $0.25 \%$ trypsin into $0.05 \%$ with Phosphate buffered saline 7.4 and filter sterilize and store at $4{ }^{\circ} \mathrm{C}$

19. Scintillation fluid

We use Ecolite scintillation fluid to measure radioactivity in aqueous solutions and Beta max to measure radioactivity in organic solvents

20. Collagen

Dissolve $10 \mathrm{mg}$ of collagen in $10 \mathrm{ml}$ of $0.1 \mathrm{~N}$ acetic acid and mix it for $3 \mathrm{~h}$ at room temperature, then dilute collagen to $50 \mu \mathrm{g} / \mathrm{ml}$ in PBS and store at $4{ }^{\circ} \mathrm{C}$

21. Collagen coating

Equilibrate collagen to room temperature and add $1 \mathrm{ml}$ to each well of 24-well plate, incubate at room temperature for $5 \mathrm{~min}$. After incubation completely remove all collagen by pipetting. Collagen is reusable at least for 10 times.

\section{Acknowledgments}

This assay protocol is developed from the method of Rutti et al. (2009). This work was supported by funding from National Institute of Health grant RO1HL131340 to B.W. 


\section{Competing interests}

Authors have no conflicts of interest to disclose

\section{$\underline{\text { References }}$}

1. Breslow, D. K., Collins, S. R., Bodenmiller, B., Aebersold, R., Simons, K., Shevchenko, A., Ejsing, C. S. and Weissman, J. S. (2010). Orm family proteins mediate sphingolipid homeostasis. Nature 463(7284): 1048-1053.

2. Davis, D., Kannan, M. and Wattenberg, B. (2018). Orm/ORMDL proteins: Gate guardians and master regulators. Adv Biol Regul 70: 3-18.

3. Davis, D. L., Gable, K., Suemitsu, J., Dunn, T. M. and Wattenberg, B. W. (2019). The ORMDL/Orm-serine palmitoyltransferase (SPT) complex is directly regulated by ceramide: Reconstitution of SPT regulation in isolated membranes. J Biol Chem 294(13): 5146-5156.

4. Ferreira, C. R., Goorden, S. M. I., Soldatos, A., Byers, H. M., Ghauharali-van der Vlugt, J. M. M., Beers-Stet, F. S., Groden, C., van Karnebeek, C. D., Gahl, W. A., Vaz, F. M., Jiang, X. and Vernon, H. J. (2018). Deoxysphingolipid precursors indicate abnormal sphingolipid metabolism in individuals with primary and secondary disturbances of serine availability. Mol Genet Metab 124(3): 204-209.

5. Gable, K., Gupta, S. D., Han, G., Niranjanakumari, S., Harmon, J. M. and Dunn, T. M. (2010). $\underline{A}$ disease-causing mutation in the active site of serine palmitoyltransferase causes catalytic promiscuity. J Biol Chem 285(30): 22846-22852.

6. Han, G., Gupta, S. D., Gable, K., Niranjanakumari, S., Moitra, P., Eichler, F., Brown, R. H., Jr., Harmon, J. M. and Dunn, T. M. (2009). Identification of small subunits of mammalian serine palmitoyltransferase that confer distinct acyl-CoA substrate specificities. Proc Natl Acad Sci U S A 106(20): 8186-8191.

7. Hanada, K. (2003). Serine palmitoyltransferase, a key enzyme of sphingolipid metabolism. Biochim Biophys Acta 1632(1-3): 16-30.

8. Hanada, K., Hara, T., Nishijima, M., Kuge, O., Dickson, R. C. and Nagiec, M. M. (1997). $\underline{A}$ mammalian homolog of the yeast LCB1 encodes a component of serine palmitoyltransferase, the enzyme catalyzing the first step in sphingolipid synthesis. $J$ Biol Chem 272(51): 3210832114.

9. Hornemann, T., Penno, A., Rutti, M. F., Ernst, D., Kivrak-Pfiffner, F., Rohrer, L. and von Eckardstein, A. (2009). The SPTLC3 subunit of serine palmitoyltransferase generates short chain sphingoid bases. J Biol Chem 284(39): 26322-26330.

10. Hornemann, T., Wei, Y. and von Eckardstein, A. (2007). Is the mammalian serine palmitoyltransferase a high-molecular-mass complex? Biochem J 405(1): 157-164. 
11. Ikushiro, H., Hayashi, H. and Kagamiyama, H. (2001). A water-soluble homodimeric serine palmitoyltransferase from Sphingomonas paucimobilis EY2395T strain. Purification, characterization, cloning, and overproduction. J Biol Chem 276(21): 18249-18256.

12. Lowther, J., Naismith, J. H., Dunn, T. M. and Campopiano, D. J. (2012). Structural, mechanistic and regulatory studies of serine palmitoyltransferase. Biochem Soc Trans 40(3): 547-554.

13. Nagiec, M. M., Baltisberger, J. A., Wells, G. B., Lester, R. L. and Dickson, R. C. (1994). The LCB2 gene of Saccharomyces and the related LCB1 gene encode subunits of serine palmitoyltransferase, the initial enzyme in sphingolipid synthesis. Proc Natl Acad Sci U S A 91(17): 7899-7902.

14. Rutti, M. F., Richard, S., Penno, A., von Eckardstein, A. and Hornemann, T. (2009). An improved method to determine serine palmitoyltransferase activity. J Lipid Res 50(6): 1237-1244.

15. Siow, D. L. and Wattenberg, B. W. (2012). Mammalian ORMDL proteins mediate the feedback response in ceramide biosynthesis. J Biol Chem 287(48): 40198-40204.

16. Williams, R. D., Wang, E. and Merrill, A. H., Jr. (1984). Enzymology of long-chain base synthesis by liver: characterization of serine palmitoyltransferase in rat liver microsomes. Arch Biochem Biophys 228(1): 282-291.

17. Siow, D., Sunkara, M., Dunn T.M., Morris, A.J., Wattenberg, B. (2015). ORMDL/serine palmitoyltransferase stoichiometry determines effects of ORMDL3 expression on sphingolipid biosynthesis. J Lipid Res. 56 (4): 898-908. 